\title{
Socio-Environmental Paradigm of Architectural Knowledge and Russian Strategies for Urban Formation
}

\author{
Konstantin Kiyanenko ${ }^{1, *}$
}

\author{
${ }^{1}$ Vologda State University, Vologda, Russia \\ *Corresponding author. E-mail: kiyanenko_k@yahoo.com
}

\begin{abstract}
This paper is about the systems of architectural knowledge in terms of their connections with strategies of urban formation. The author's concept of paradigms of socio-architectural knowledge is a theoretical basis of research. Each paradigm is a set of social models, incl. models of a human being, of life, of environment-making and others. The same approach of models analysis characterizes the social strategies of urban formation as presented in the works of Russian authors. To identify the content of social models two methods applied: conceptual and terminological analysis of texts on the platform of e-library.ru and scientometric analysis of the planning literature. Three strategies were identified and considered, urban construction, urban regulation and urban arrangement, which have proven to be more or less favorable conceptual contexts for the implementation of the socio-environmental approach to the formation of the city.
\end{abstract}

Keywords: strategies of urban formation, paradigms of socio-architectural knowledge, strategy

\section{INTRODUCTION}

A study of the links between the spheres of social knowledge in architecture and urban formation gave life to this paper ${ }^{1}$. Its purpose is to clarify the theoretical aspects of the ongoing tectonic shift in these two areas. First, the boundaries between them, previously vague in Russia, are becoming clearer. Second, the very area of urban formation is splitting. It is the spin-off from Soviet type urban construction of two nascent strategies - urban regulation and urban arrangement. Both the legitimacy of emphasizing of namely these two new phenomena among the others, and their status as just rhetoric or as independent strategies opposing urban construction require justification, understanding and explanation.

The shifts in urban strategies stem from the projection of political, economic, and socio-cultural processes of the last three decades onto the field of architectural knowledge. They cause a large-scale transformation of all conceptual filters, which architects and planners use in order to perceive, study, simulate,

*Fund: The reported study was funded by Science and Technology Development State Program of the Russian Federation for years 2013-2020, Program of Fundamental Research of State Academies of Science for years 2013 - 2020, within Program of Fundamental Researches of Ministry of Construction, Housing and Utilities of the Russian Federation and Russian Academy of

Architecture and Construction Sciences, the Research Project 1.4.6.

The concept of urban formation is being used in this paper as an umbrella term, embracing various strategies of dealing with the city. and reproduce the socio-architectural reality. These filters bear the name social models.

The author's concept of paradigms of socioarchitectural knowledge lies in the foundation of the research - several theoretical platforms that hinges around a key model, a human being as an inhabitant of the world and a client of the architect [1]. Theoretical work on residential architecture demonstrates the coexistence of at least five such paradigms: functionalist, interactionist, consumerist, environmental, and phenomenological. They treat a person as a subject of action or social interaction, as a consumer, a subject of behavior, and a "true" inhabitant of a "life-world". Each interpretation of the human being predetermines the content of other social models: society as a creator of the city, the processes of living and shaping architectural objects, social criteria for assessing their quality.

Methods of research are "conceptual and terminological" and scientometric analysis of texts stored in the electronic library of Russia - e-library.ru. Based on previous research, the concepts-descriptors of individual paradigms of knowledge were isolated. Selected and processed were texts whose authors denoted the three strategies for urban formation in the titles, annotations, and / or keywords of their publications. The texts have been considered through the prisms of the concepts-descriptors. The research demonstrates the links between strategies of urban formation and paradigms of socio-architectural knowledge. It became clear that the socio- 
environmental paradigm is a theoretical basis of the most humanistic strategy of urban arrangement.

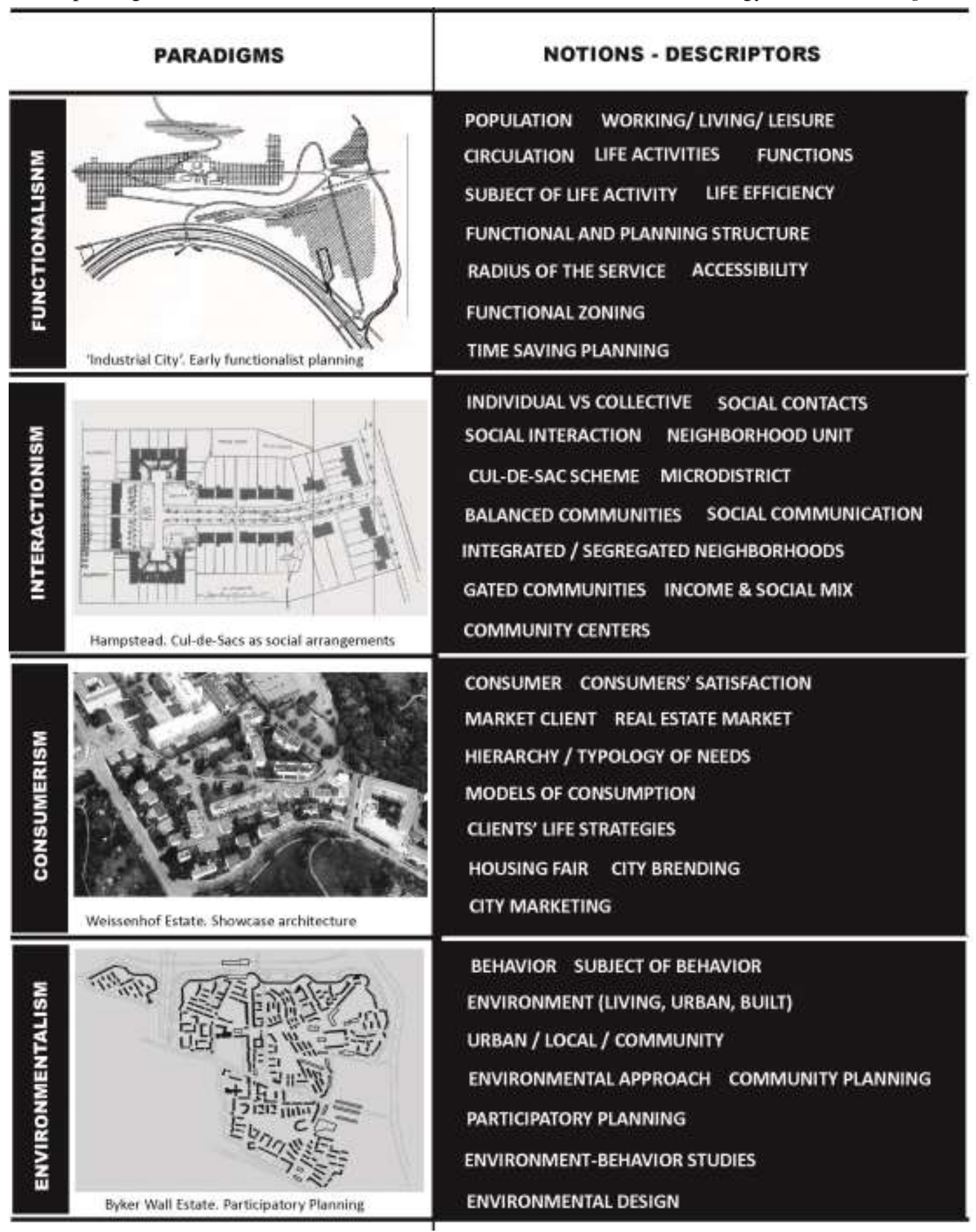

Fig. 1. Paradigms of social knowledge in theories of urban formation, and the notions that identify them.

\section{GLOSSARIES OF PARADIGMS OF SOCIO- ARCHITECTURAL KNOWLEDGE}

The field of social knowledge in architecture falls apart into relatively independent plots. The architects who occupy these plots have different understanding of the human figure, of the content of life they organize and of the socio-spatial structures of space. They evaluate quality of design and professional activities according to different criteria and build their vision upon the foundations of different scientific disciplines, theories and ideologies, address their architecture to 
different public clients and segments of professional practice. The question remained open, weather these consistent patterns from the theory of residential architecture exist in theory of urban formation? Since the paradigms of socio-architectural knowledge reveal themselves in the use of different concepts and terms and their peculiar interpretation, the answer to this question required conceptual and terminological analysis of papers in theory of urban formation. The results of the analysis of a number of texts widely recognized in the profession, and appealing to concepts that distinguish the specifics of paradigms, are shown in the "Fig. 1"2.

As it could be anticipated, in terms of the underpinning social models, theory of residential architecture and theory of urban formation follow the same general laws. The diversification of basic social models is clearly evident in these disciplines. The notions presented in "Fig. 1" were then applied for analysis of the texts, which belong to the three strategies of urban formation.

\section{RUSSIAN URBAN FORMATION STRATEGIES}

Any communication about creating, recreating, or developing a city is complicated by the fact that there is no mutually agreed and commonly used conceptual apparatus for this talk in modern Russia. Primarily this refers to the concept that denotes the very branch of the relevant theory and practice. From the point of view of many, the traditional concept of urban construction can no longer play the role of a comprehensive one ${ }^{3}$. It is incurably infected with the virus of administrativecommand, over-centralized mentality and approach. Some suggest urban arrangement instead [2] [3] [4]. Others promote urban regulation concept [5] [6] [7]. These two pretendants are theoretically more justified than the others, which also exist. The following table presents a scientometric analysis of all these concepts in terms of frequency of use ("Table I").

TABLE I. FREQUENCY OF USE OF THE CONCEPTS, DENOTING THE PLANNING STRATEGIES (IN E-LIBRARY.RU).

\begin{tabular}{c|c}
\hline Notions - strategies & $\begin{array}{c}\text { Number of } \\
\text { publications }\end{array}$ \\
\hline
\end{tabular}

2 From classical texts of E. Howard, Le Corbusier, A. and P. Smithson up to the textbooks, monographs and papers of L.N. Avdot'yin, Yu. P. Bocharov, A. A. Vysokovsky, V.L. Glazychev, A. E. Gutnov, L.B. Kogan, V. A. Kolyasnikov, A.V. Krasheninnikov, I.G. Lezhava, I.M. Smolyar, Z. N. Yargina.

3 Russian term gradostroitel'stvo serves to replace internationally accepted urban planning in this country, but literally speaking it means construction of cities or urban construction as it is used in this paper.

4 The sampling is based on the number of publications that use the related concept in the titles, annotations, and / or keywords of three types of sources: journal articles, books, and conference materials.

\begin{tabular}{c|c}
\hline $\begin{array}{c}\text { urban construction } \\
\text { (gradostroitel"stvo) }\end{array}$ & 7457 \\
\hline $\begin{array}{c}\text { urban regulation } \\
\text { (gradoregulirovanie) }\end{array}$ & 162 \\
\hline $\begin{array}{c}\text { urban arrangement } \\
\text { (gradoustroystvo) }\end{array}$ & 109 \\
\hline urban erection (gradostroenie) & 226 \\
\hline $\begin{array}{c}\text { urban generation } \\
\text { (gradoobrazovanie) }\end{array}$ & 110 \\
\hline $\begin{array}{c}\text { urban formation } \\
\text { (gradoformirovanie) }\end{array}$ & 36 \\
\hline urban planning (gradoplanirovanie) & 33 \\
\hline
\end{tabular}

The concept of urban construction is still dominating, but alternatives to it exist. What are the differences between these strategies in terms of social content ${ }^{6}$ ?

\section{IV. "PARADIGMS" VS. "STRATEgIES"}

Further research included selection of the texts of identified adherents of each of the three strategies based on the number of citations in e-library.ru, and academic status of the texts (preference was given to scientific monographs, university textbooks and fundamental articles). Four-part matrices present the results of the analysis, while each quadrant accommodates the concepts that characterize a certain social model of the human / social being, of the contents of life, of city creator, and a process of creating a city. Together they represent the "social portrait" of individual strategies for urban formation. From top down, the concepts unfold in the order of frequency of use. 


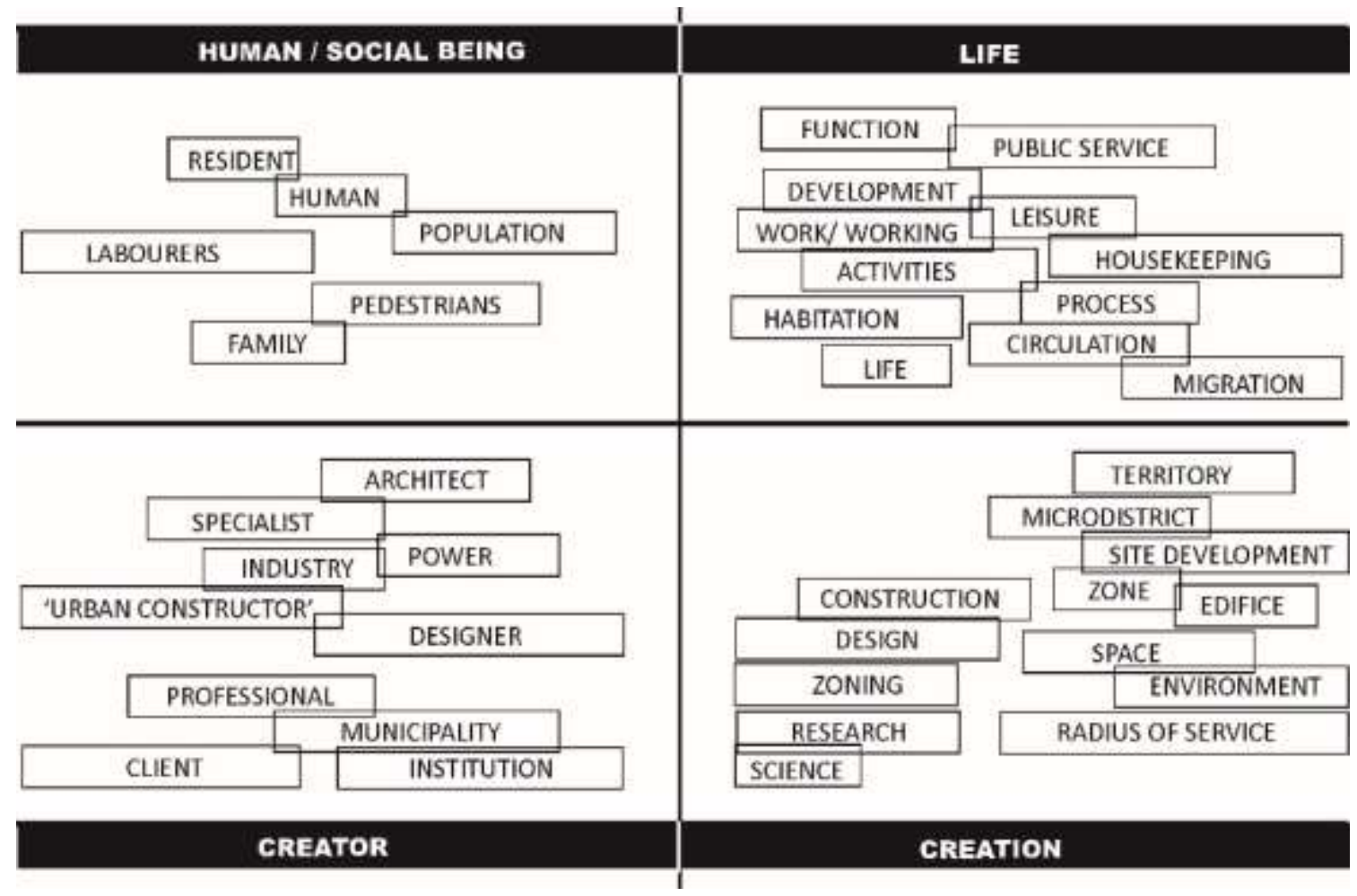

Fig. 2. Social lexicon of urban construction strategy.

Two fundamental texts fully represent lexicographic features of the urban construction strategy [8] [9]. As evidenced by the texts, its authors express their thoughts in a mainly functionalist language ("Fig. 2").

In urban construction city appears as a spatial resource for implementation of social functions, and activities in their most obvious, observable, positivist forms - work, life, recreation, and movement. People are subjects of activity, urban population, residents, families, and in the pre-reform text, are also labourers. Architects, planners (urban constructors) and other specialists and professionals as well as authorities, industries and municipalities are the key figures in creating the cities ${ }^{7}$. The processes of creating the city, for obvious reasons, emphasize planning, design, zoning, construction. The results of this strategy of actions bear the names of territories, microdistricts, zones, buildings, spaces.

The claim that urban construction shares a functionalist vision is at first glance contradicted by frequent reference to the concept of the environment. But the analysis of specific contexts shows that the notions of environment and living environment are used most unsociably here - as "spaces, surrounding buildings", as synonyms of "developed territories". The

7 The special role of architects is symptomatic, since Soviet style urban construction recognizes the concepts of architect and urban planner as almost synonymous. expression "the environment closest to an architectural monument" is very characteristic of the urban construction lexicon [10]. 


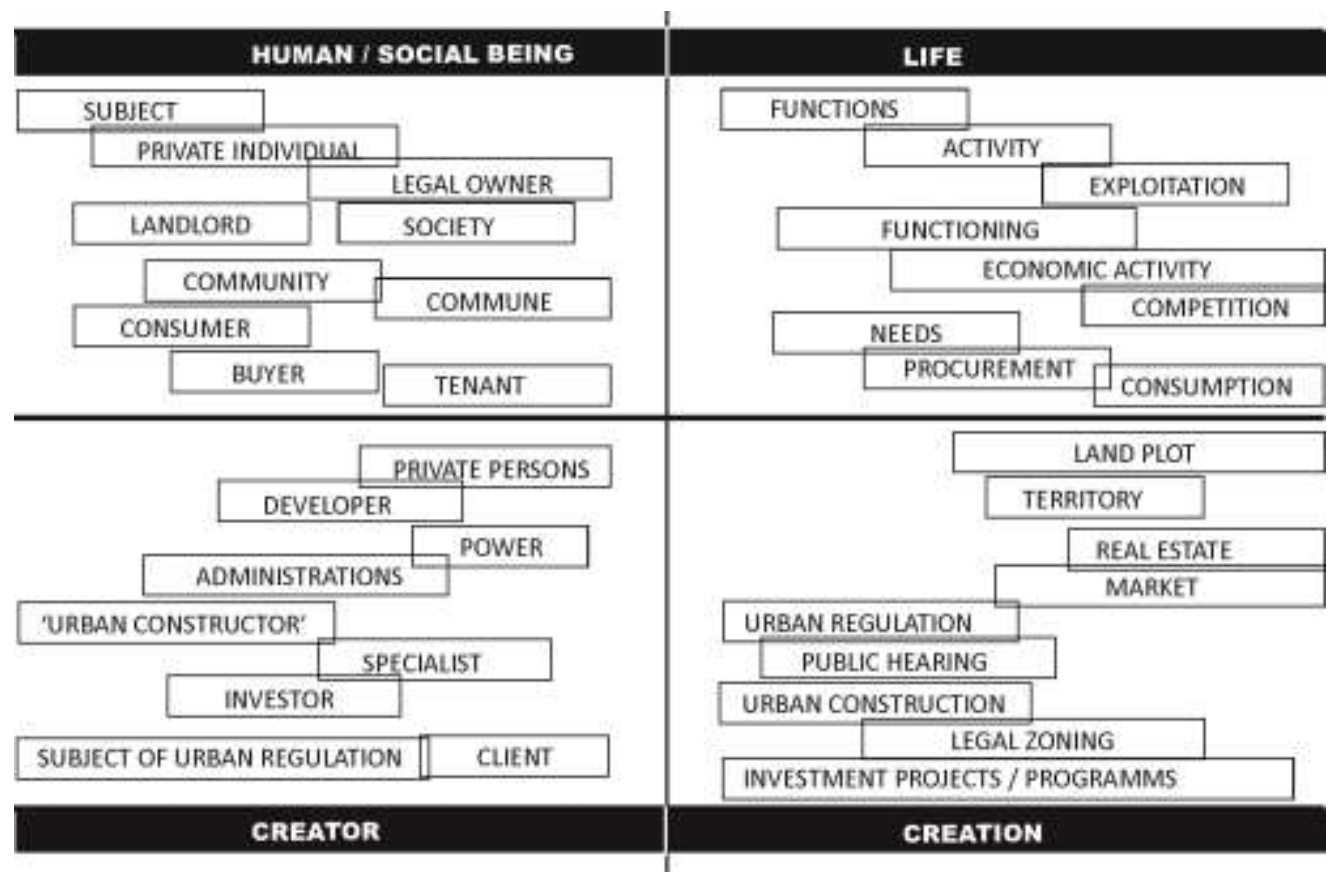

Fig. 3. Social lexicon of urban regulation strategy.

One work - both fundamental and cited - became the main source for analysis of urban regulation [11]. The basic social vocabulary of this strategy is shown in "Fig. 3".

The conceptual apparatus of urban regulation differs from urban construction. People here are legal owners of real estate, private individuals, and independent subjects. Society, community, and commune are popular notions, but they are treated rather as aggregates of private persons than transpersonal entities. The most common notionsdescriptors of life - are functions, functioning, and activities that seem to bring this strategy close to urban construction. The difference is that in urban construction this is a generalized Corbusian "work, life, leisure, circulation", and in urban regulation "primary functions of the subject", inclusive of private economic activity. Functioning more often relates to real estate market than to humans as modernist biomachines.

The driving forces of urban regulation are private persons, developers, city administrations. The notion of architect appears only once and this is for a good reason. He is a source of arbitrariness for urban legal regulation, its domain is "architectural and construction design" of buildings. The main object and product of urban regulation, an elementary portion of a liberal city is a land plot. Other essential concepts include territory, real estate, and real estate market. In contrast to the territory in urban construction, here it is not as much a resource for activity as a set of regulations, types of permitted usage, forms of ownership, and a set of land plots. In general, urban regulation tends to the language of the consumerist paradigm.

Texts on urban arrangement demonstrate the internal heterogeneity of this strategy. It was hard to create a single matrix of key concepts that would not enter into semantic contradictions with each other. The main differences between the various "schools" of urban arrangement are rather ideological than theoretical. The right flank, represented by the texts of A.A. Vysokovsky, is in many respects close to the liberal attitudes of urban regulation, but is more socially, culturally, humanistically oriented, and less economically blinkered. Apparently, it is not by chance that in his paper, Vysokovsky does not refer to the concept of urban regulation, using urban arrangement $[12]^{8}$

The left wing of this spectrum was a domain of a group of sociologists led by T.M. Dridze, who actively collaborated with architects and urban constructors from the early 1990s on and critically perceived the market with its obvious flaws [13]. There are also "centrists" among the authors in the urban arrangement segment. Soberly assessing both administrative urban construction and unregulated market, paying tribute to the environmental vision and social essence of urban processes, they focus on the practice of forming "livable" cities [14].

8 In his turn, E.K. Trutnev, despite the closeness of his and A.A. Vysokovsky's positions on 296 pages of the monograph on urban regulation, mentions the urban arrangement only twice. 


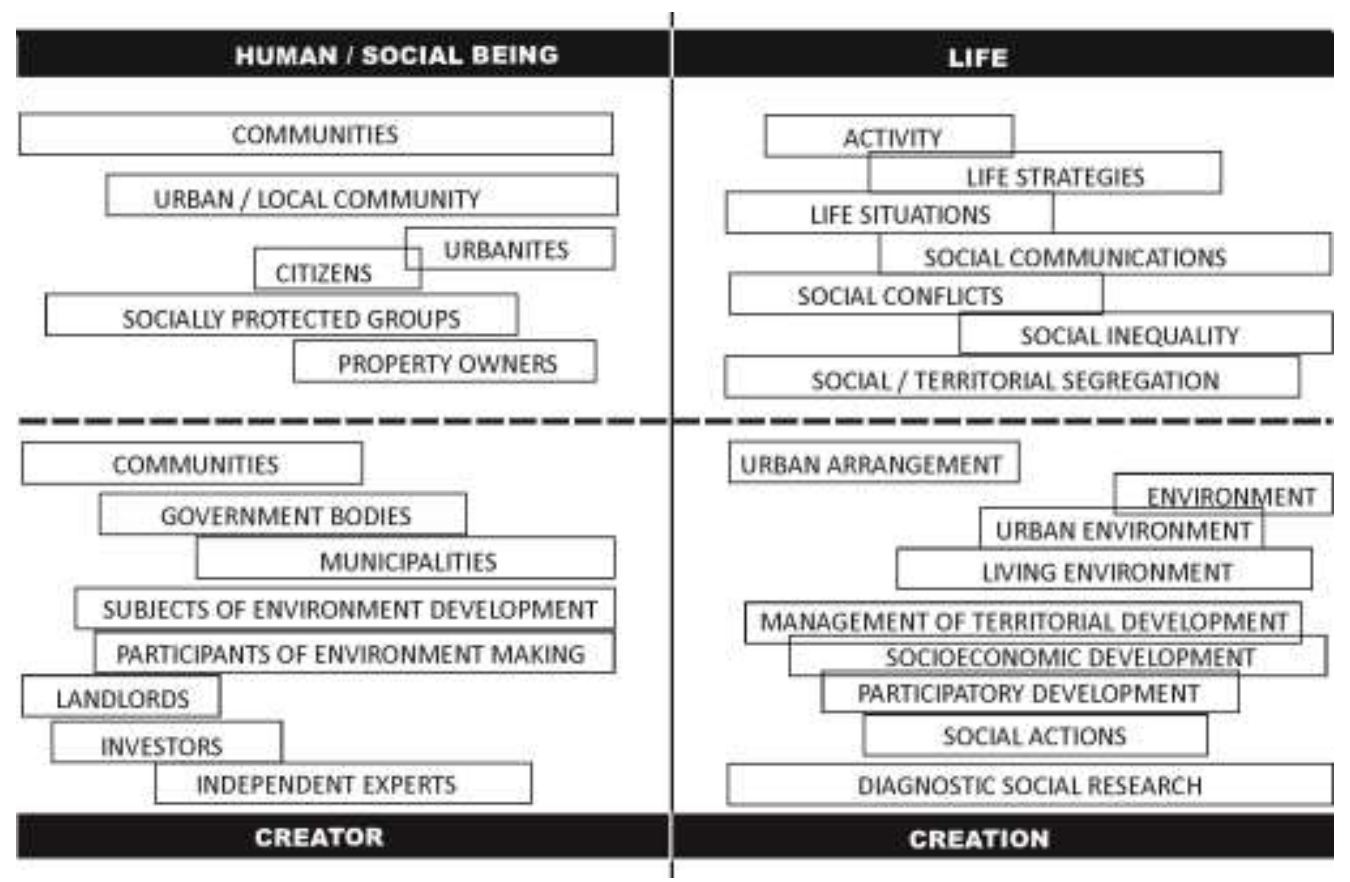

Fig. 4. Social lexicon of urban arrangement strategy.

In an effort to cover the entire spectrum of the strategy, the paper focuses on the social models of urban arrangement on the left flank of this strategy. For its authors, city is populated by urban communities, urbanites, citizens, connected with the urban environment by various socio-cultural and psychological strands ("Fig. 4").

An attentive planner ${ }^{9}$ distinguishes between variety of life situations, life strategies, detects social communications, social conflicts, manifestations of social inequality, social stratification, all that reliably cures from idealization of the market. Local community is not only a collective inhabitant, but also a subject of environment development, in cooperation with government bodies, as well as investors, and landlords. The dotted line between the quadrants symbolizes the fact that the inhabitants and the creators of environment are the same entities. Creation of the urban environment and management of territorial development, rely on technologies of participation. Project decisions are made or should be made on the basis of diagnostic social research, in the interests of socioeconomic development.

Thus, both the lexicon of the urban arrangement on its left flank and the interpretation of individual concepts clearly indicate theoretical connection of this strategy with the socio-environmental paradigm of knowledge.

9 This is a self-name that proponents of urban arrangement prefer for themselves.

\section{CONCLUSION}

Following the gradual separation of the branches of urban formation from one side and architecture from another as spheres of practice and knowledge, the urban formation itself falls apart, and new areas appear along with traditional urban construction. Especially symptomatic are urban regulation and urban arrangement. It is obvious that they are not just a product of rhetorical exercises, but new and different strategies that differ from both urban construction and each other. In particular, the differences relate to the socio-conceptual worlds, the attraction to different models of the social, the societal lexicon of each of the strategies.

Divergence of social vision between individual strategies have a fundamental character. Each strategy of urban formation uses conceptual filters of particular paradigms of social knowledge, starting with a fundamentally different interpretation of the person and the urban community as the inhabitants and creators of the city. Urban construction reflects a functionalist vision, but it also shares certain concepts of interactionism. The language of consumerism is closer to urban regulation. The urban arrangement, being a conceptually heterogeneous strategy, embraces socioenvironmental knowledge with its left wing.

The concepts of environment, society, and community are popular in all strategies of urban formation. But, only urban arrangement uses them in a more theoretically meaningful and strict manner, - as 
socio-physical integrities. That is why it distinguishes objects, processes, and qualities in the urban life that are invisible for other strategies. These are the socioenvironmental paradigm as a theoretical basis, vision of the city as an urban environment, and urban population as local communities, attention paid to the sociocultural content of life, to the problems of urban society, that make urban arrangement the most humane and therefore promising strategy for the urban formation.

\section{References}

[1] K.V. Kiyanenko, Housing Architecture and Social Modelling: Summary of D. Arch. Dissertation: 18.00.02 / Moscow Architectural Institute, Moscow, 2005, 62 p. [in Russian]

[2] A.A. Vysokovskiy, Urban Arrangement: Tasks for Professional Development // Alexander Vysokovskiy: in 3 vol. Vol.1: Theory, Moscow: Grey Matter, 2015, pp. 380-397. [in Russian]

[3] V.L. Glazychev, Russian Space Arrangement // Izvestiya KazGASU. 2009. No 1(11). Pp.41-44. [in Russian]

[4] A.A. Shagova, Transition Period: From Urban Construction to Urban Arrangement // Territory and Planning. 2009. No 6(24). Pp.66-79. [in Russian]

[5] D.G. Dontsov, Urban Regulation as a Strategic Direction for Improving Urban Development Activities // Bulletin of Volgograd State University of Architecture and Civil Engineering. Series: Construction and Architecture. 2005. No 5. Pp. 188-195. [in Russian]

[6] L.G. Tarasova, Paradigms" Shift in the Development of the Theory and Practice of Urban Construction // Architecture and Construction of Russia. 2009. No 3. Pp.29-37. [in Russian]

[7] "Urban Regulation: Fundamentals of Regulation of Urban Development Under the Conditions of Formation of Real Estate Market" / [Trutnev, E.K. et. al.]; head of the author"s team E.K. Trutnev, Moscow: Foundation "The Institute for Urban Economics", 2008, 296 p. [in Russian]

[8] L.N. Avdot"in, Urban Construction Design: Textbook for Higher Education Institutions / L.N. Avdot”in, I.G. Lezhava, I.M. Smolyar, Moscow: Stroyizdat, 1989, 432 p. [in Russian]

[9] G.A. Maloyan, Fundamentals of Urban Construction, Moscow: Izdatel"stvo Assotsiatsii Stroitel"nykh Vuzov, 2004, 120 p. [in Russian]

[10] Ibid.

[11] "Urban Regulation: Fundamentals of Regulation of Urban Development...”, op. cit.

[12] A.A. Vysokovskiy, op. cit.

[13] T.M. Dridze, Social Diagnostics in Urban Arrangement // Sociological Studies. 1998. No 2. Pp. 94-98. [in Russian]

[14] A.N. Beregovskikh, From Urban Construction to Urban Arrangement, Omsk, 2018, 424 p. [in Russian] 